\title{
A 40 años de la Noche de las Corbatas: La función social del abogado laboralista ayer y hoy
}

\author{
Por Zarina Surache ${ }^{1}$
}

Quienes hacemos ReDeA entendemos a la teoría y la praxis jurídica como muestra de una realidad que por un lado es dinámica (con lo cual nos lleva a estar en un proceso de adaptación permanente a los cambios que se producen) y por otro nos interpela a participar activamente considerándonos una parte fundamental del devenir histórico y como "garantes" de la operatividad de principios fundamentales que se expresan en el derecho positivo y en la doctrina.

En este contexto particular que existe actualmente, nos urge replantearnos nuestro rol como abogados, docentes, operadores jurídicos y actores sociales en general y en esta línea no podemos dejar de lado el análisis de ciertos sucesos que marcaron nuestra historia reciente y tienen vinculación directa con la evidente función social que tiene el abogado.

A modo de introducción, diremos que se conoce la noche de las corbatas al conjunto de secuestros de abogados y familiares (11 personas en total), ocurridos entre el 6 y 13 de Julio de 1977 en la ciudad de Mar del Plata a manos de los grupos de tareas de las Fuerzas Armadas que actuaban en forma ilegal durante la última dictadura cívico militar.

Entre las víctimas de los sucesos mencionados se encuentran:

- Salvador Manuel Arestín (abogado) Desaparecido.

- Raúl Hugo Alaiz (abogado) Desaparecido

- Camilo Ricci (abogado) Sobreviviente

- Carlos A. Bozzi (abogado) Sobreviviente

- Tomás J. Fresneda (abogado) Desaparecido

- María de las Mercedes Argañaraz de Fresneda (Embarazada de cuatro meses) Desaparecida.

- Néstor Enrique García Mantica Desaparecido

- María Esther Vázquez de García (esposa del anterior) Desaparecida 
- José Verde (ex secretario General de la Asociación Judicial Bonaerense Mar del Plata). Sobreviviente

- Esposa del anterior. Sobreviviente

- Norberto Centeno (abogado) Asesinado

De las victimas mencionadas de los trágicos sucesos es quizá Norberto Centeno el nombre más conocido, en virtud de la trascendencia que tuvo su obra, de la cual realizamos seguidamente un análisis pormenorizado.

En la década del ' 40 y del '50 Centeno trabajó como inspector de Salubridad e Higiene en la Secretaría de Trabajo y Previsión.

Se recibió de escribano en la Universidad Nacional del Litoral y de abogado en la Universidad Nacional de La Plata en 1956.

La dictadura autodenominada Revolución Libertadora (Argentina) que derrocó al presidente Perón ordenó su encarcelamiento debido a su militancia peronista.

En 1960, fue detenido por el gobierno de Arturo Frondizi aplicando el Plan Conintes de movilización militar de la población, debido a su adhesión a las huelgas declaradas por las asociaciones sindicales. Volvió a ser detenido en 1969 y 1976.

Profesionalmente, fue asesor legal en el ámbito de diversas asociaciones sindicales, entre ellas: Confederación General del Trabajo ; Federación Sindicato Unido Petroleros del Estado (SUPE); Unión de Trabajadores Gastronómicos (UTGRA); Unión Obrera Metalúrgica (UOM); Sindicato Único de Trabajadores Edificios de Renta y Propiedad Horizontal de Mar del Plata; Unión Argentina de Artistas de Variedades (UADAV); Sindicato Trabajadores Industria de la Alimentación; Sindicato de Luz y Fuerza de Mar del Plata y Sindicato Camioneros y Obreros del Transporte.

Colaboró también con la asesoría letrada de la Asociación Obrera Textil, del Sindicato de Trabajadores de la Industria del Hielo y de Mercados Particulares y Afines así como de la Federación Argentina de Trabajadores Rurales y Estibadores (FATRE).

En 1974 redactó un anteproyecto, principal antecedente del Régimen de Contrato de Trabajo aprobada ese año por la ley 20.744, y que constituye la ley laboral más importante de la historia argentina actualmente vigente con sus reformas y leyes complementarias.

En los juicios por la verdad llevados adelante como respuesta a las leyes de Punto Final y Obediencia Debida que impidieron investigar hasta su anulación en 2003 la suerte corrida por las víctimas de la dictadura militar y sus responsables, María Eva Centeno, hija de Norberto Centeno, declaró: Mi padre era especialista en Derecho del Trabajo, autor de dos libros sobre la materia, y numeroso material en revistas especializadas. Se desempeñaba como abogado del Sindicato de Choferes, Unión Gastronómica, Unión Obrera 
Metalúrgica y Asociación Obrera Textil, así como asesor de la C.G.T. regional Mar del Plata y Capital Federal. El día 7 de julio del año 1977, a la salida del estudio jurídico donde desarrollaba sus tareas mi padre, fue interceptado por un grupo de gente armada. De ello se tiene conocimiento posterior por versión de un testigo presencial. El 11 de julio del año 1977, aparece el cadáver de mi padre, dejándose constancia en el certificado de defunción que su muerte data del día 9 de julio, y dándose como causa del deceso "shock traumático hemorrágico". La desaparición de mi padre se produce en forma simultánea con la de otros profesionales, de los cuales uno solo recupera su libertad, el Dr. Carlos Bossi, quien es encontrado en el baúl del automóvil que mi padre conducía el día de su secuestro. En base al testimonio de la Sra. Marta García (Legajo No 7290), llega a mi conocimiento que, en el momento de ser ella alojada en el centro de detención llamado "La Cueva," sitio en la Base Aérea de Mar del Plata, ubica a mi padre. El mismo había sido objeto de torturas y ella tiene un contacto directo con él, al humedecerle los labios, ya que se quejaba de terribles dolores. Con posterioridad en una segunda sesión de tortura, mi padre fallece, apareciendo su cadáver, tal como he manifestado, el día 11 de julio de 1977.

Resolución judicial del caso: En febrero de 2012, la Cámara Federal de Casación Penal confirmó el fallo dictado el el 9 de Junio de 2010 por el Tribunal Oral en lo Criminal Federal de Mar del Plata, en virtud del cual se condenó al ex suboficial de la Fuerza Aérea Gregorio Rafael Molina a la pena de prisión perpetua por haber considerado que los homicidios de Centeno y Candeloro (cuyos cuerpos si fueron localizados) encuadraban jurídicamente en la categoría de crímenes de lesa humanidad.

Es en virtud de los hechos ocurridos en esa fecha, que la Federación Argentina de Colegios de Abogados optó por conmemorar el 6 de Julio como el "Día Nacional del Abogado víctima del terrorismo de Estado" y también es considerado como el día del Abogado Laboralista.

\section{La función social del abogado laboralista ayer y hoy}

Si nos detenemos a hacer una revisión sobre la obra de los abogados víctimas del terrorismo de Estado en un sentido general y sobre el legado y la obra de Centeno en particular encontramos que anteriormente a la redacción y la sanción de la Ley de Contrato de Trabajo las relaciones de trabajo eran regidas por otras normativas más genéricas sobre contrataciones civiles como el Código Civil. En este sentido, la ley 20.744 fue un hito en tanto que significó la consolidación de un proceso que llevó años para construir un marco normativo específico que incluyera a los principios generales del Derecho del Trabajo en la regulación positiva de los vínculos laborales. Se trata de un proceso que comienza incluso antes del constitucionalismo social y en el cual intervienen actores sociales individuales y colectivos. 
En este contexto, podemos concluir en que el rol del Derecho del Trabajo y del abogado laboralista como operador jurídico tiene que ver precisamente con lograr que los principios generales del Derecho del Trabajo (propios de nuestra disciplina y de su carácter tuitivo) se enraícen cada vez más como normas operativas que rijan el antes, el durante y la extinción de los vínculos laborales.

Es claro, en este punto, que la regulación de las relaciones laborales de manera tal que su existencia se den lo más armónicamente posible se logra en tanto los principios generales que la inspiran tengan por objetivo y por bien jurídico el restablecer un equilibrio entre partes que resulta inicialmente roto en razón de las condiciones materiales que rodean a una y a otra parte del contrato.

El análisis que antecede puede llevarnos a pensar que si la legislación laboral y su práctica jurídica tiende a restablecer un equilibrio que inicialmente no se presenta como tal, el hecho de la persecución, secuestro, desaparición forzada y en su caso asesinato de abogados laboralistas tiene por motivación el evitar que las normas jurídicas y su aplicación pueda influir directamente en las prácticas culturales existentes respecto de las relaciones de trabajo y cuestionarlas, principalmente porque cuestionar las mismas significaría cuestionar un status quo de desequilibrio económico y social mucho más profundo.

Seguidamente, si nos detenemos a analizar el estado actual de la teoría y la practica en materia de derecho laboral, nos encontramos con que el rol del abogado laboralista sigue siendo el lograr la operatividad de los principios generales y su aplicación a través de las normas positivas. Entonces, la aplicación de esas normas sigue significando un constante cuestionamiento respecto de una situación de desequilibrio material que se intenta remediar (aún más después de la reforma constitucional de 1994 que incorpora estos principios a través de Pactos y Tratados con Jerarquía Constitucional).

Entonces, no resulta sorprendente el constante desprestigio al que los abogados laboralistas somos sometidos cotidianamente por parte de los sectores concentrados de la política, la economía y los medios de comunicación que hacen que la ciudadanía se haga eco de conceptos que son en su mayoría sesgados. Si bien no resulta sorprendente por cuanto no es algo novedoso ni propio del momento actual, sí representa un peligro claro por cuanto los abogados en general y los laboralistas en particular desempeñamos un rol de profunda importancia social, no solo por nosotros mismos sino porque el desprestigio al derecho laboral y a sus operadores jurídicos es una embestida en contra de la posibilidad que tenga el trabajador de obtener mejores condiciones de labor y de hacerlas valer, ya sea individual o colectivamente.

Abogada Laboralista, Auxiliar Docente Cátedra II de Derecho Social, del Trabajo y Previsión de la Facultad de Ciencias Jurídicas y Sociales de la UNLP. 
